УДК 373.2.016:81-028.31

DOI:

Ірина Паласевич, кандидат педагогічних наук, дочент кафедри загальної педагогіки та дошкільної освіти Дрогобииького державного педагогічного університету імені Івана Франка

\title{
РОЗВИТОК ЗВ'ЯЗНОГО МОВЛЕННЯ СТАРШИХ ДОШКІЛЬНИКІВ ЗАСОБОМ СЮЖЕТНИХ КАРТИН
}

У статті розкрито особливості розвитку зв язного мовлення стариих дошкільників засобом сюжетних картин; охарактеризовано основні методи та прийоми навчання дітей розповідання за змістом сюжетних картин; доведено, щзо командний метод складання розповіді активізує процес зв 'язного мовлення, зміцнює засвоєння структури висловлювань, привертає увагу дітей до власного мовлення та висловлювань однолітків, спонукає до оцінки розповідей; акиентовано увагу на тому, щуо виконання дітьми творчих завдань, складання віртуальних діалогів, перевтілення (входження в образ) у конкретний об'єкт на картині, вихід за межі зображуваного привносять у їхні розповіді оригінальні сюжетні лінії, підтримуючи високий рівень інтелектуальної та мовленнєвої активності, сприяючи формуванню якостей самостійного зв'язного висловлювання.

Ключові слова: діти старшого дошкільного віку; розвиток зв 'язного мовлення; сюжетні картини; навчання дітей розповідання; методи та прийоми навчання дітей розповідання; творче розповідання.

Jim. 11.

Iryna Palasevych, Ph.D.(Pedagogy), Associate Professor of the General Pedagogy and Preschool Education Department, Drohobych Ivan Franko State Pedagogical University

\section{DEVELOPMENT OF COHERENT SPEECH OF THE OLDER PRESCHOOLERS BY MEANS OF PLOT PAINTINGS}

The article is revealed the peculiarities of the development of coherent speech of the older preschoolers by means of plot paintings; described the main methods; described the main methods and process of teaching children the storytelling by plot of pictures; it is proved that the command method of storytelling activates the process of a coherence speech, firms the assimilation of the structure of utterances, attracts the childern's attention to their own speech and peers, motivates to the assessments of stories.

Attention is drawn to the fact that children perform creative tasks; creating of virtual dialogs; dialogues between living and nonliving objects based on the plot of the picture; reincarnation (entering into an image) in the concrete object in the picture; going beyond the image; image pantomime of his image; a story from the one of the characters in the painting; creating of narratives, rhymes; dramatizing games on the content of the picture bring in their story the original storylines, maintaining high level of intellectual and speech activity, contributing to the formation of such the qualities of an independent connected statement as meaningful, logical consistency, imagery and creativity.

It is found out that in the statements of older preschoolers clearly traced the pilot line determine the content of the story, structural organization of the text, the use of various means of communication between the content parts of the statement.

Important significance is acquired in the course of studying the narration on the basis of a plot of a scene and an analysis of the stories of children. Senior preschoolers are actively involved into the analysis of their own stories and stories from their friends. This moment in the classroom is expedient to use to improve the coherent speech of children, directing them to a more successful lexical replacement, the selection of additional options for the characterization of the image, plot line, sentence structure, story structure etc.

Keywords: children of the senior preschool age; development of coherent speech; story paintings; teaching children a story; methods and techniques of teaching children a storytelling; creative storytelling.

П остановка проблеми. Своєчасний мовленнєвий розвиток дошкільника забезпечує оптимальні умови для якнайповнішого розкриття його потенційних здібностей та суб'єктних проявів, становлення особистості, котра адекватно, доречно, вільно і творчо використовує мову в різних життєвих ситуаціях, володіє формулами мовленнєвого етикету, розвинутими комунікативними здібностями. Власне тому все більшої актуальності набуває розвиток зв'язного мовлення дітей як одного із засобів самовираження, особливо 3 огляду на сенситивність дошкільного віку щодо природної емоційності і мовленнєвої чутливості.

Важливе місце в системі засобів розвитку 
зв’язного мовлення дошкільників займає сюжетна картина, яка містить конкретно-чуттєвий матеріал для розповіді, збуджує їхні уяву й почуття, розвиває мислення, спонукає до вияву самостійності, ініціативи й творчості. У дітей формується свідоме художньо-естетичне сприймання, активізується мовленнєво-творча діяльність, яка за умови правильно організованого навчання сприяє розвиткупочаткових літературнохудожніх здібностей, стимулює та збагачує інші види дитячої творчості.

Аналіз останніх досліджень і публікацій. Зазначимо, що зв'язне мовлення дітей дошкільного віку досліджується науковцями в різних аспектах: розвиток діалогічного мовлення (А. Арушанова, А. Богуш, Н. Гавриш, В. Любашина, А. Чулкова та ін.); навчання дітей різних видів розповідей: описової (А. Дементьєва-Бородич [5], Н. Зеленко [6], С. Ласунова, Л. Порядченко, О. Тихеєва та ін.), розповіді-роздуму(А. Омеляненко, Н. Харченко та ін.), творчого розповідання (Л. Березовська, О. Білан, А. Богуш [1 - 3], Н. Гавриш [1 - 4], Н. Орланова, О. Смирнова [8], А. Яценко [11]); переказування дітьми художніх творів (А. Богуш, Н. Гавриш, О. Лещенко, Н. Малиновська та ін.); розвиток зв'язного мовлення упродовж ігрової (В. Захарченко, Н. Луцан [7], Н. Савінова) та продуктивно-творчої діяльності (Н. Гавриш, Т. Постоян та ін.). Значна частина праць з означеної проблеми присвячена розробці системи ігрових мовленнєвих вправ та ситуацій, мовленнєво-творчих занять, спеціальних прийомів навчання дітей зв'язного діалогічного й монологічного мовлення, методичних рекомендацій iз використання демонстраційних картин, ілюстрацій до художніх творів, серій сюжетних картин тощо.

Водночас практика засвідчує, що зазвичай сюжетна картина використовується лише для збагачення й активізації словника дітей, розвитку в них діалогічного мовлення, а не для планомірного, цілеспрямованого навчання розповіді, розвитку в дітей здатності цілісно сприймати сюжет картини, встановлювати зв'язки в зображених ситуаціях, поєднувати змістові частини висловлювання, зберігаючи структуру тексту. Часто на заняттях застосовуються одноманітні методи й прийоми розвиткузв' язного мовлення дітей, без урахування їхніх вікових можливостей. Відтак усвідомлення значущості окресленої проблеми спонукало до вибору теми пропонованої статті, метою якої $є$ обгрунтування особливостей розвитку зв'язного мовлення старших дошкільників засобом сюжетних картин.
Виклад основного матеріалу. Сучасні лінгводидакти увиразнюють два аспекти зв'язного мовлення - власне процес створення самостійного зв'язного висловлювання та результат цього процесу, продукт мовленнєвої діяльності - текст, що включає такі послідовні етапи, як: визначення теми, планування сюжетної лінії, добір необхідних мовних засобів, розповідання й самооцінка готового продукту (тексту) [2, 450].

Так, у дослідженні Н. Смольникової обгрунтовано можливість формування у старших дошкільників умінь структурно правильно будувати тексти, використовуючи при цьому різноманітні зв'язки між реченнями й частинами висловлювання. Авторка наголошує, що формування навичок самоконтролю й самооцінки у навчально-мовленнєвій діяльності дітей забезпечує довільність та усвідомленість у побудові їхніх розгорнутих монологічних висловлювань [9].

Період дошкілля є надзвичайно важливим для розвитку зв'язного мовлення майбутньої особистості. У цьому віці діти можуть послідовно й чітко складати описову та сюжетну розповідь на запропоновану тему, висловлювати міркування, переконливо їх аргументувати. Ускладнюється синтаксична структура дитячих розповідей; активно застосовується пряма мова, засоби художньої виразності. Ще вищим рівнем $є$ пояснювальне мовлення, яке передбачає розвинуте мислення дитини i вміння встановлювати та відображати у мовленні причиново-наслідкові зв'язки. Це зумовлено потребою старшого дошкільника пояснити однолітку зміст майбутньої гри, різноманітні ігрові дії з предметами, домовлятися про здійснення ігрового задуму, об'єднуватися з ровесниками на основі рольової взаємодії тощо. Саме в ігровій діяльності дітей, як зазначає Н. Луцан, виявляється образність і виразність їхнього мовлення, в якому вони активно поєднують мовні та позамовні засоби виразності $[7,121]$.

Упродовж старшого дошкільного віку відбувається поступовий перехід від переважно діалогічного спілкування до розгорнутих висловлювань, які нерідко набувають форми монологу, за допомогою якого дитина ділиться 3 іншими своїми почугтями, думками, коментує власні дії, фіксує знання про себе й довкілля. Таке мовлення нагадує коротке оповідання, в якому відображено найцікавіше, те, що вразило, схвилювало. Старший дошкільник усвідомлює мовлення як об'єктивну реальність, приділяє увагу його фонетичному, лексичному та граматичному аспектам. 
У Програмі “Українське дошкілля” виокремлено такі показники компетентності дитини шостого року життя щодо розвитку зв'язного мовлення, як уміння: 1) складати описові розповіді різного типу: сюжетно-описові, сюжетні за картинками, 3 власного досвіду, за зразком та планом вихователя; 2) складати творчі розповіді: продовжувати розповідь, яку розпочав вихователь, за опорними словами, за сюжетноігровою ситуацією, розповідь-міркування, розповідь-пояснення; 3) переказувати знайомі художні тексти різної складності за планом вихователя та за частинами; 4) поділяти сюжетну картину на логічно завершені частини, придумувати назву до них; 5) об'єднувати кілька сюжетів в єдину розповідь (розповіді за серією картин, ілюстрацій, порівняльні розповіді); 6) складати казки, загадки; 7) давати розгорнуті відповіді на запитання 3 монологічними вставками; 8) підтримувати запропонований діалог відповідно до теми; 9) будувати стимульований діалог відповідно до ситуації; 10) володіти формулами мовленнєвого етикету [10, 222 - 223].

Разом із тим, у багатьох дітей перелічені вміння ще нестійкі. Це виявляється у змістовій (наслідування зразка, алогічність і непослідовність змісту, бідність та неоригінальність сюжетів) та формальній характеристиках висловлювання (порушення структури висловлювання, обмеженість у використанні стилістичних засобів), труднощі в реалізації набутих художньоестетичних уявлень у власній творчості [6].

Надзвичайно ефективним засобом розвитку зв'язного мовлення дошкільників фахівці вважають сюжетну картину, що передбачає виокремлення декількох композиційно цілісних складових, об'єднаних єдиним сюжетом, змістом картини.

Серед чинників, що впливають на глибину та адекватність сприймання дітьми сюжетних картин, А. Богуш та Н. Гавриш виокремлюють рівень художньо-естетичного сприймання, життєвий та художній досвід дітей, доступні для розуміння зміст і тематикукартин, а також правильно організований процес їх розглядання $[4,48]$.

Структура заняття 3 навчання розповіді за змістом сюжетних картин включає дві частини: організація сприймання дітьми змісту картини та керівництво процесом розповідання. Зауважимо, що успішність чи продуктивність другої частини заняття, тобто якість дитячих розповідей, значною мірою залежить від продуманої, ретельно проведеної першої, яка забезпечує глибоке сприймання та усвідомлення дітьми картини.
Так, організацію сприймання дітьми змісту картини у старшому дошкільному віці можна розпочати з аналізуії назви. Наприклад: “Картина називається “Свято на лісовій галявині”. Як ви вважаєте, чому саме так вона називається? Як, на вашу думку, можна було б назвати їі поіншому? Чому?”. Наведені питання дають змогу дітям оцінити картинузагалом, щоб потім перейти до детальнішого їі розгляду. Звернення до власного досвіду дошкільнят, участь у полілозі з теми заняття, лексико-граматичні вправи активізують розумову та мовленнєву діяльність вихованців, спонукають їх до вияву ініціативи. Доречними є проблемні запитання, що передбачають аналітичні дії та вміння самостійно складати судження. Розгорнута відповідь стає природним результатом інтелектуально-мовленнєвої активності. Дитина висловлює власну думку, для формулювання якої вона самостійно чи 3 допомогою вихователя добирає ті мовленнєві засоби, які найповніше передають задум мовця.

Серед прийомів навчання дітей розповідання А. Дементьєва-Бородич вважає найбільш ефективними зразок розповіді вихователя; складання розповідей за частинами; план розповіді; колективний його аналіз; запитання; підказка; вказівка; оцінка дитячої розповіді [5]. Поступово зразок розповіді вихователя від повного на початкових етапах навчання змінюється частковим (вихователь надає дитині зразок лише одного 3 фрагментів майбутньої розповіді, пропонуючи інші елементи скласти самостійно) або зразком-дублером (на прикладі відстороненого зразка розповіді демонструє, як треба іiї будувати). Зазначимо, що мовленнєвий зразок вихователя є чудовим орієнтиром у складанні дітьми розповідей, проте надмірне захоплення ним спричиняє гальмування самостійності дитини в доборі мовленнєвих засобів їх адекватного висловлювання. У навчанні старших дошкільників зразок використовують лише в окремих випадках, зумовлених відповідною ситуацією [3, 11].

Ефективним прийомом сприймання дітьми змісту сюжетної картини, окрім запитань, $є$ : а) ігрові та логічні, творчі завдання (наприклад, “Вихід за межі зображеного”); б) віртуальні діалоги, які допомагають уявно “увійти” в ситуацію, зображену на картині; в) діалоги між живими й неживими об'єктами за сюжетом картини; г) перевтілення (входження в образ) у конкретний об' єкт на картині; д) зображення пантомімою свого образу; е) розповідь від імені одного з персонажів картини; є) складання описових загадок, римівок; ж) ігри-драматизації 
за змістом картини. Якщо дошкільнятам важко виконувати творчі завдання, складати віртуальні діалоги, їм можна запропонувати спочатку колективне сюжетоскладання, допоки вони не виявлять готовності до самостійної реалізації завдань такого типу.

Командний метод складання розповіді активізує процес зв'язного мовлення, засвоєння структури висловлювань, привертає увагу дітей до власного мовлення та висловлювань своїх товаришів, спонукає до оцінки розповідей. Командні розповіді - один із найрезультативніших способів навчити дітей розповідання, оскільки вони не почуваються самотніми (команда складається $34-5$ осіб - за бажанням вихованців). Якщо розповідь складається командою, то власний внесок кожного члена команди відповідно буде меншим, посильним навіть для найнесміливіших. Завдяки командним розповідям під час заняття участь у складанні розповіді беруть майже всі діти. Розповідь командами - це ефективний спосіб забезпечення не лише високої мовленнєвої активності задіяних у занятті 12 - 16 дітей, а й розвитку зв'язності висловлювань та стимулювання творчості дошкільнят (кожна команда не повторює попередньої розповіді, а складає власну).

Якщо командний метод складання розповіді сприяє насамперед розвиткузв'язності мовлення, то метод моделювання фіксує увагу дітей на змістовому аспекті, тобто на побудові сюжетної лінії, послідовності основних епізодів розповіді. Суть моделювання полягає в тому, що за допомогою певних схематичних позначок чи предметів-замінників діти моделюють послідовність розгортання сюжетної лінії, тобто перед розповіданням складають план розповіді в картинках або символах [4, 42].

Як стверджує А. Яценко, мовленнєво-творча діяльність дітей під час розповідання за змістом сюжетних картин стане більш ефективною, якщо грунтуватиметься на прагненні дошкільнят до експериментування над мовним матеріалом, до виконання винахідницьких завдань, спрямованих на формування вміння сприймати зображення через уявні можливі відчуття від зіткнення 3 різними об'єктами, уявні звуки, смаки та аромати й передавати їх у зв'язному висловлюванні.

Методичні поради щодо навчання дітей творчого розповідання (фантазування) А. Яценко сформулювала у вигляді “шести кроків”, а саме:

1. Виокремлення об’єктів, зображених на картині (Чарівник “Ділийко”).

2. Встановлення різного рівня зв'язків i взаємодій між об’єктами (Чарівник “Додавайко”).
3. Опис картини за допомогою різних аналізаторів (Чарівники: “Я тільки чую”, “Я відчуваю запах”, “Я сприймаю дотиком”, “Я відчуваю смак”).

4. Опис картини засобами прямої та символічної аналогії. Скарбничка образних характеристик (Чарівник “Порівняйко”).

5. Створення оповідань-фантазій із використанням прийому переміщення в часі (Чарівник "Відставай - забігай”)

6. Складання оповідань від імені будь-якого героя. Точка зору (Чарівник “Перетворяйко”) [11, $12-13]$.

На нашу думку, заохочення дітей до виконання перелічених творчих завдань забезпечить високий рівень їхньої інтелектуальної, емоційної та мовленнєвої активності, дасть змогу зберегти упродовж усього заняття гарний настрій та живий інтерес до процесу сприймання, а також спонукатиме висловити свої враження у власній розповіді.

Старших дошкільників навчають творчого розповідання за серією сюжетних картин, що “унаочнює логічну структуру (початок - зав’ язка - основна частина - кульмінація - розв’язка) розповіді, яку складають діти, візуалізує планування власного висловлювання, сприяе формуванню таких якостей мовлення, як плавність, зв'язність, логічність” $[1,3]$.

У монографії О. Смирнової доведено, що упродовж індивідуальної та колективної розповіді формуються вміння дітей поєднувати змістові частини висловлювання, зберігаючи структуру тексту, використовувати різноманітні зачини розповіді, синонімічні заміни при назві героїв, їхніх дій і станів. У висловлюваннях старших дошкільників усе чіткіше простежується сюжетна лінія, визначаються змістові частини розповіді при переході від однієї картинки до іншої, структурна організація тексту, використання різноманітних засобів зв'язку між змістовими частинами висловлювання [8].

Методика проведення цього виду занять розроблена А. Богуш та Н. Гавриш. Науковці пропонують п’ять способів презентації сюжетних картин. Так, перший iз них передбачає послідовний розгляд картин, із яких відкрита на початку заняття лише перша. Перед тим, як показати наступну, вихователь пропонує дітям здогадатися, що на ній зображено. Тільки коли фантазія вихованців вичерпується, вихователь демонструє картину. Це дає змогу підтримувати інтерес до заняття тривалий час. До кожної 3 картин вихователь добирає відповідні запитання та лексико-граматичні завдання (вправи, ігри, 
творчі завдання). За кожною картиною складається розповідь, обсяг якої поступово збільшується: спочатку тільки за змістом першої картинки, згодом - першої та другої; першої, другої та третьої тощо.

Другий спосіб презентації сюжетних картин полягає в одночасному поданні дітям усіх картинок, які вони самі мають розмістити в логічній послідовності. Потім заняття відбувається за стандартною схемою послідовний розгляд кожної картини за запитаннями та складання розповідей.

Умови третього способу - три перші картини закриті, остання відкрита. Перша частина заняття передбачає колективні творчі фантазії дітей щодо початку розповіді. Пізніше послідовно відкриваються картини і складаються розповіді.

На відміну від перших трьох, за четвертого способу на початку заняття відкриваються перша та остання картинки. Після фантазування дітей про зміст середніх картинок послідовно розглядаються всі картинки, за якими складаються розповіді.

Останній, п'ятий спосіб презентації сюжетних картин характеризується показом картинок через одну [1, 6-7].

На таких заняттях особлива увага вихователя спрямовується на коригування зв'язного мовлення дітей. Старших дошкільників навчають розповідання за кожною структурною частиною (спочатку скласти початок, потім серединуі кінцівку), підбирати до однієї назви різні варіанти початку, різні кінцівки або ж тільки іншу середину, замінити героїв тощо. Наприкінці заняття діти складають розповідь 3 усіма структурними частинами, аналізують її відповність наміченому плану.

Важливого значення набувають упродовж навчання розповідання за сюжетною картиною оцінка та аналіз розповідей дітей. Старші дошкільники беруть активну участь в аналізі власних розповідей та розповідей своїх товаришів. Цей момент на занятті доцільно використовувати для вдосконалення зв'язного мовлення дітей, спрямовуючи їх на більш вдалу лексичну заміну, добір додаткових варіантів щодо характеристики образу, сюжетної лінії, будови речення, структури розповіді тощо.

Висновки. Отже, необхідною умовою навчання дітей розповідання за сюжетною картиною $є$ систематична цілеспрямована робота над формуванням уміння сприймати iї сюжет, встановлювати зв'язки в зображених ситуаціях, поєднувати змістові частини висловлювання. Правильний добір картин, поступове ускладнення завдань, методів і прийомів навчання роблять його доступним, цікавим та ефективним. Виконання творчих завдань, складання віртуальних діалогів, вихід за межі зображуваного привносять у розповіді дітей оригінальні сюжетні лінії, підтримуючи високий рівень інтелектуальної й мовленнєвої активності, сприяючи формуванню таких якостей самостійного зв'язного висловлювання, як змістовність, логічна послідовність, образність і креативність.

Запропонована стаття, звісно, не вичерпує всіх аспектів розглядуваної проблеми. Перспективними напрямами подальших досліджень вважаємо аналіз інноваційних технологій підготовки майбутніх вихователів до формування мовленнєвої компетенції дітей старшого дошкільного віку.

\section{ЛІТЕРАТУРА}

1. Богуш А., Гавриш Н. Вчимося розповідати. Складання розповідей за серіями сюжетних картин на основі літературних творів : навч.метод. посіб. К. : МЦФЕР-Україна, 2013. 32 с.

2. Богуш А.М., Гавриш Н.В. Дошкільна лінгводидактика : теорія і методика навчання дітей рідної мови в дошкільних навчальних закладах / за ред. А.М. Богуш. - 2-ге вид., допов. К. : Слово, 2011. 704 с.

3. Богуш А.М., Гавриш Н.В. Запрошуємо до розмови.Розповідання засюжетними картинами : навч.метод. комплект для дітей старш. дошк. віку : метод. посіб. та 16 картин, 2-ге вид. К. : Генеза, 2014. 48 с.

4. Гавриш Н. Розвиток зв'язного мовлення дошкільнят : навч.-метод. посіб. К. : Шкільний світ, 2006. 120 с.

5. Дементьева-Бородич А.М. Методика развития речи детей : учебное пособие для студ. пед. ин-тов по специальности “Дошкольная педагогика и психология”. 2-е изд. М. : Просвещение, 1981. 255 с.

6. Зеленко Н.І. Особливості розповіді дітей п’ятого року життя за сюжетними картинками. Дошкільна педагогіка та психологія. 1978. № 11. C. $18-25$.

7. Луцан Н.І. Розвиток зв'язного мовлення дошкільників в мовленнєво-ігровій діяльності : лінгводидактичний аспект. Наука і освіта. 2014. № 10. С. $119-122$.

8. Смирнова Е.А. Обучениестарших дошкольников рассказыванию по серии сюжетных картин. М. : Просвещение, 1987. 204 с.

9. Смольникова Н.Г. Формирование структуры связного высказывания у старших дошкольников : автореф. дисс. ... канд. пед. наук : 13.00.02 / НИИ дошк. восп. Москва, 1986. 23 с. 
10. Білан, О.І., Возна, Л.М., Максименко О.Л. та ін. Українське дошкілля : програма розвитку дитини дошкільного віку. Тернопіль : Мандрівець, $2013.264 \mathrm{c}$.

11. Яценко А.В. Джерельце творчості. ТРВ3. Х. : Ранок, 2011. 176 c.

\section{REFERENCES}

1. Bohush, A. \& Havrysh, N. (2013). Vchymosia rozpovidaty. Skladannia rozpovidei za seriiamy siuzhetnykh kartyn na osnovi literaturnykh tvoriv [Learning the words. Writing stories based on plot in literature]. Kyiv : MTsFER-Ukraina Publ., 32 p. [in Ukrainian].

2. Bohush, A. \& Havrysh, N. (2011). Doshkilna linhvodydaktyka : teoriia $i$ metodyka navchannia ditei ridnoi movy $v$ doshkilnykh navchalnykh zakladakh [Preschool linguodidactics: the theory and methods of teaching children of native language in preschool educational institutions]. Kyiv : Slovo Publ., 704 p. [in Ukrainian].

3. Bohush, A. \& Havrysh, N. (2014). Zaproshuiemo do rozmovy. Rozpovidannia za siuzhetnymy kartynamy [Inviting to speaking. Storytelling by plot of pictures]. Kyiv: Heneza Publ., 48 p. [in Ukrainian].

4. Havrysh, N. (2006). Rozvytok zviaznoho movlennia doshkilniat [Development of preschoolers' coherent speech]. Kyiv : Shkilnyi svit Publ., 120 p. [in Ukrainian].

5. Dementeva-Borodic, A.M. (1981). Metodika razvitiya rechi detey [Methods of children' speech development]. Moskva : Prosveshchenye Publ., 255 p. [in Russian].

6. Zelenko, N.I. (1978). Osoblyvosti rozpovidi ditei piatoho roku zhyttia za siuzhetnymy kartynkamy [Specifics of storytelling of five years old children based on plot pictures]. Preschool pedagogy and psychology. No. 11, pp. 18 - 25. [in Ukrainian].

7. Lutsan, N.I. (2014). Rozvytok zviaznoho movlennia doshkilnykiv $\mathrm{v}$ movlennievo-ihrovii diialnosti : linhvodydaktychnyi aspekt [Development of coherent speech of preschoolers in speech-game activities: linguodidactic aspect]. Science and education. nr 10. pp. 119 - 122. [in Ukrainian].

8. Smirnova, Ye.A. (1987). Obuchenie starshikh doshkolnikov rasskazyvaniyu po serii syuzhetnykh kartin [Teaching of senior preschoolers based on series story paintings]. Moskva : Prosveshchenie Publ., 204 p. [in Russian].

9. Smolnikova, N.G. (1986). Formirovanie struktury svyaznogo vyskazyvaniya u starshikh doshkolnikov [Formation of the structure of the coherent expression in the older preschoolers]. Moskva, 23 p. [in Russian].

10. Bilan, O.I., Vozna, L.M., Maksymenko, O.L. et al. (2013). Ukrainske doshkillia : prohrama rozvytku dytyny doshkilnoho viku [Ukrainian preschool : a program for the development of a child of preschool age]. Ternopil : Mandrivets Publ., 264 p. [in Ukrainian].

11. Iatsenko, A.V. (2011). Dzhereltse tvorchosti. TRVZ [Source of creativity. Technology of solution of inventive tasks]. Kharkiv : Ranok Publ., 176 p. [in Ukrainian].

Стаття надійшла до редакції 08.02.2019

\title{
G5808n
}

“Сдиний, хто не втомлюється, - час. А ми живі- нам треба поспішати".

\author{
Ліна Костенко \\ уқраїнська письменниия
}

“Вільний час учителя - це корінь, яқий живить джерела педагогічної творчості”.

Василь Сухомлинський

украйнський педагог

"У всіх справахнаставник-практика".

Невідомий автор

“Завтрашній день - найважливіша річ у житті. Він відвідує нас опівночі. Ћудово, коли він приходить і віддається прямо в наші руки. Він сподівається, що ми хоч чомусь навчилися відучора".

Dжон Вейн

американський актор

\section{G58080ल2058080}

